\title{
Use of Main or Branch Library Web Pages on Public Access Computers in Academic Branch Libraries: Results of a Listserv Inquiry
}

\section{Anita Breckbill and Virginia Baldwin}

\begin{abstract}
Some academic branch libraries display a main library Web page as the default home page for their public computers. Others display a branch library page. In response to an inquiry sent to selected listservs, librarians from sixty-three academic institutions provided information about the choice and content of their default home pages. Although the numbers from the study do not clearly favor either choice, this paper, in summarizing the librarians' input, provides insight into other available options and the considerations that contribute to maximum user benefit for a given library and library system.
\end{abstract}

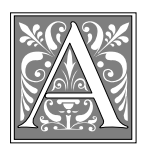

cademic libraries exist to provide access to information for their patrons. In the past ten years, public Web sites have become the first point of contact when patrons access an academic library online. "The web site has become one of the academic library's most visible artifacts for communicating with users, and the home page has become the starting point for users conducting library research to explore the resources available." ${ }^{\prime 1}$ It has become increasingly important for libraries to evaluate their home pages in order to verify that the information they give their patrons is pertinent, clearly presented, and internally consistent.

Many academic library systems have a main library Web site that is shown as the default screen on public computers in all of their libraries. ${ }^{2}$ A patron can go to any library in the system and expect to see the same interface. However, a significant number of library systems have one or more branch libraries that provide a Web site that is unique to the branch as the default screen on their public computers.

The authors of this article have different opinions about which primary interfacea main library Web site or a branch library Web site-is most useful in a branch library setting. One of the authors, a music librarian, favors using the main library Web site as the default screen on all public computers. She prefers the consistency among libraries in a system. Moreover, she notes that her library trains all the freshmen in the university using the main library interface and fears that confusion would result if the student walked into a branch library and 
saw a different interface than that used in his or her training. She also agrees with Eelko K. R. E. Huizingh, who says that a larger site is a richer site. ${ }^{3}$ Her coauthor, an engineering librarian, thinks it is of utmost importance that patrons who walk into the engineering library be presented, on the first screen of the public computers, with the information that is specifically useful to them. According to her, the engineering resources are too hidden on the main library interface, and she wants a patron in the engineering library to be able to access an engineering database with one click of the mouse.

\section{In the past ten years, public Web sites have become the first point of contact when patrons access an academic library online.}

How to resolve this dissension among library professionals? The authors decided to ask other libraries what they did. The goal of this study is to find out what other academic branch libraries have chosen to use as the default screen on their public computers: the main library Web site or the branch library Web site.

\section{Literature Review}

The autonomy of a branch library is one important issue in the discussion of Web page presentation. In the library literature of previous decades, writers have dealt richly with issues of centralization versus decentralization in libraries. Some of their arguments remain valid in the discussion of Web page choice. The ACRL Guidelines for Branch Libraries in Colleges and Universities, written in 1990 before the prevalence of Web pages, asserted that "A branch library's programs must provide for the requirements of its primary clientele as well as the cross-disciplinary needs of others in the academic community." ${ }^{\prime 4}$ It goes on to say that "Branch libraries typically have a special relationship with one or more academic departments.... At the same time, a branch library must be integrated into the central library system and serve the entire university community." ${ }^{\prime 5}$
The balancing act required of a branch library is also stressed in a 1994 article by Olivia M. A. Madison, Sally A. Fry, and David James Gregory that commented on these guidelines: "The evolving national discussion on academic branch libraries is now firmly centered on how well they meet the needs of a primary clientele [and] how thoroughly they are integrated into the larger library system." ${ }^{16}$ Some comments in the literature of this time would lead to favoring the main Web page as the default page. One source has noted that "Branch facilities are often seen by administrators as duplicative, both in terms of collections and staffing," and, it might be added, Web page creation. ${ }^{7}$ Other comments have favored branch autonomy, which is consistent with the use of the branch page as the default page. Leon Shkolnik stated that "The quality of the branch depends on its responsiveness to the needs of the community it serves. Once this responsiveness becomes questionable, so does the reason for having a branch library." ${ }^{8}$ In 1998, Odin Jurkowski noted how powerful branch libraries have become, partially because they are able to mirror their main library in terms of information retrieval of items available on the Internet. "Branch librarians can take it a step further and design their own Web site," he wrote. "They may wish to organize a page of links more relevant to the needs of that particular branch ... as an option instead of going straight to the main library Web site." ${ }^{\prime 9}$ In an ominous tone, he encouraged a branch to "take charge" because "the main campus often forgets about the branch libraries."10 On a more encouraging note, the 1994 Madison, Frey, and Gregory article stated that "academic branches are ... models for the library of the future-entrepreneurial, flexible, and client-centered, functioning not as isolated units but as interconnected nodes in a sophisticated information network."11 These are all comments that can be considered in the discussion of which Web site to use as a default page.

There have been numerous articles in recent years about analyzing library Web sites for their design and usability. Laura 
B. Cohen and Julie M. Still compared Web sites from research universities with those in two-year colleges to identify a core common content for academic library Web sites. ${ }^{12}$ David L. King examined the home pages of 120 Association of Research Libraries (ARL) members to identify trends and note the attributes of a typical library home page design. ${ }^{13}$ Barbara I. Dewey, who quoted one source as saying its library Web site needed a "demolition and rebuilding" project, noted the difficulty of building library Web sites. The common problems are that:

1. Users do not understand categories.

2. The design is built on an individual library's organizational structure, not intuitive

3. Service features are buried.

4. The Web sites contain too much information, poorly placed. ${ }^{14}$

No published articles were found that specifically address the issue of what Web site is shown as a default screen to patrons in branch libraries, but Karen Diaz summarized the dichotomy: "In a Webbed world, duplication of effort is not only wasteful, it is confusing to users. There is a need to ensure that the same information is not being maintained in several different places with several different rates of upkeep." 15 This statement would argue for a single Web site being consistently used as the main Web site. However, Diaz went on to say, "Yet we need to be flexible enough to realize that librarians serving very specific segments of users know those segments best and know what is going to be most effective in communicating with that population."16 This would argue for branch librarians, with their knowledge of their own users, creating and using their own Web sites. ${ }^{17}$

In his analysis of ready reference Web sites in libraries, Steven Sowards quoted the well-known aphorism: "Choose any two: good, fast, cheap." He paraphrased it to say: "Choose any two: (1) clear organizations to guide user; (2) immediate access to hot links for all URLs; and (3) extensive resource content." Sowards noted that choosing 1 and 2 would lead to a smaller, less robust sitein this study, the typical branch Web page-

and choosing 1 and 3 would lead to a larger site, burdened by the complexity that comes with size-in this study, the typical main library Web site.

With library literature focusing on a balancing act, this issue begged for a direct questioning of branch librarians. What do they use as the home page for the public computers in their libraries?

\section{Methodology}

To identify the choices made by branch libraries in colleges and universities, the authors queried librarians using a variety of listservs. Direct communication was necessary because it is impossible to determine what site is used as the default for the browser on public access computers at the library without visiting each library. Table 1 gives the listservs that were polled and the fields of study covered by the listserv.

The question sent to the listservs was phrased as follows:

I have a question for Academic Librarians in Branch Libraries: What do you use as the home page for the public computers in your library?

I am assuming there are three basic possibilities:

1. The Main Library's home page

2. Your Branch Library's home page (the one an outside user would get to by selecting your library from the Main Library's home page) 3. The public computer's home screen is different from either of the above.

TABLE 1

Listservs Surveyed

\begin{tabular}{ll} 
Listserv Name & Listserv Coverage \\
\hline sts-1 & Science and technology \\
mla-1 & Music \\
AASL-1 & Architecture \\
Usain-1 & Agriculture \\
Eldnet-1 & Engineering \\
sla-st & Science and technology
\end{tabular}


Please let me know which you use and any experience you care to relate regarding this issue. If your option is \#3, a brief description of the contents or basic differences from the branch home page would be welcome.

Many of the respondents commented that the branch libraries in their institutions could choose whether to use the main library's home page or some other home page. Some of the respondents gave an indication of the percentage of others in their system that had made a different choice. Other respondents indicated that no choice was given at their institution and only the main site could be used. Some agreed with this policy and others disagreed with it.

In many cases, the respondents provided the URLs for their main and/or branch library's site or, in the case of the third choice, some provided the actual URL of the "Other" Web site that was used for the default on their public access computers. In some cases, additional research was necessary to determine what branch library the respondent represented. This was done by searching the respondent's name on his or her university's Web site to determine the branch attributed to that respondent, and the assumption was made that the respondent's comments were in reference to that branch. Based on the comments, a fourth category was assigned"Research Gateway." In this case, all branches or some group of branches use a Web site especially designed for public access computers and that Web site is different from the one reached by following the link(s) from the university's home page to the Libraries page.

Duplication of respondents from the same institution did occur. For nine institutions, the librarians' responses were the same (all chose "Main" or all chose "Branch"). For five institutions, the librarians' responses differed from each other. There were five cases in which three respondents were from the same institution. Three of these identified all branches as using the main Web site, one identified all branches as using the branch Web site, and one was mixed (two "Main" and one "Branch") with a comment from one librarian that the ratio is about fifty-fifty among the branches. For the purposes of this study, the five institutions that had different responses from the branch libraries were placed in the "Other" category, which then was relabeled "Other or Mixed."

The institutions represented were identified as to ARL status. Results were compiled separately for unique ARL and non-ARL libraries. Results by branch library type (subject area) were compiled for both ARL and non-ARL libraries combined and separately for the ARL institutions, and were attributed to their original category ("Main," "Branch," or "Other") or to the fourth category, "Research Gateway."

This study has limitations. Responses from a listserv survey are not random in the same sense that responses from a mailed survey are. In addition, except in the cases specifically noted by the comments of the responding librarian, it is impossible to determine from the responses whether all of the branch libraries in an institution designated as "main" actually fall into the "Main" category or whether some fall into the "Branch" category. It is clear from the comments that some library systems have a policy that all libraries in the system use the main page, but it is unclear how many. Likewise, it cannot be ascertained whether those institutions placed in the "Branch" category have a library system that requires all branch libraries to have their own Web site (a possibility that seems less likely) or whether there is a mixture of "Main" and "Branch" categories at the institution. The comments were not considered when placing an institution in a category. The category designated by the responding librarian was the assigned category. With these limitations in mind, the results of the study were analyzed and conclusions drawn. Some interesting considerations were raised. 
TABLE 2

Number of Libraries Using Each Home Page Option for Unique ARL and Non-ARL Institutions

\begin{tabular}{lcccccc}
\hline \hline Library Type & Main & Branch & $\begin{array}{c}\text { Other } \\
\text { or Mixed }\end{array}$ & $\begin{array}{c}\text { Research } \\
\text { Gateway }\end{array}$ & Total & Comment \\
\hline Non-ARL & 11 & 14 & 2 & 2 & 29 & \\
ARL & 15 & 11 & 8 & 0 & 34 & $(28 \%$ response $)$ \\
\hline $\begin{array}{l}\text { Total Unique } \\
\text { Institutions }\end{array}$ & 26 & 25 & 10 & 2 & 63 & \\
\hline
\end{tabular}

\section{Results}

Respondents represented a total of sixtythree universities. Of these, thirty-four have libraries with ARL status and twenty-nine have libraries without ARL status. According to the ARL Web site, "Membership in ARL is institutional. There are currently more than 120 members." ${ }^{18}$ The actual count of links to libraries on the ARL Web site is 123. Thus, the libraries responding from the thirty-four ARL institutions represent a response rate of 28 percent of the total number of institutions with ARL libraries.

Table 2 shows the results of the responses for each of the two library types. For ARL libraries, four more respondents indicated that their library's public access computers use the main library home page rather than the branch library home page. For non-ARL libraries, three more libraries use a branch library home page rather than a main library home page. Overall, the split between main and branch was nearly identical (26 and 25).

Table 3 shows the results of the responses for each type of branch. Several categories have more than one subject area represented. These occur for two reasons: (1) the library represents more than one subject area, and (2) branch libraries with similar subject areas were grouped together. The two branch libraries that reported a "research gateway" were not included in table 3. Both of these were in non-ARL institutions.

Tabulated results in table 3 indicate that six more libraries use a main Web page than use a branch Web page. Ten percent of the eighty respondents were identified

\section{TABLE 3}

Type of Home Page Used by Branch Libraries by Subject Area, All Respondents

\begin{tabular}{lcccc}
\hline Branch Subject Area & Main & Branch & Other & Total \\
\hline Architecture & 5 & 1 & 0 & 6 \\
Chemistry, etc. & 3 & 1 & 0 & 4 \\
Mathematics & 0 & 2 & 0 & 2 \\
Biology/Life Sciences & 3 & 0 & 0 & 3 \\
Agriculture, etc. & 1 & 2 & 3 & 6 \\
Physics, etc. & 4 & 2 & 0 & 6 \\
Science/Sci\&Eng. & 6 & 4 & 0 & 10 \\
Engineering, etc. & 8 & 6 & 2 & 16 \\
Earth Sciences & 1 & 0 & 1 & 2 \\
Music & 8 & 15 & 2 & 25 \\
\hline TOTAL for ALL branches & 39 & 33 & 8 & 80 \\
TOTAL for ALL branches excluding Music & 31 & 18 & 6 & 55 \\
\hline
\end{tabular}


TABLE 4

Type of Home Page Used by Branch Libraries by Subject Area, ARL Only

\begin{tabular}{lcccc}
\hline Branch Subject Area & Main & Branch & Other & Total \\
\hline Architecture & 5 & 0 & 0 & 5 \\
Chem/CPM/ChemMath & 2 & 1 & 0 & 3 \\
Mathematics & 0 & 2 & 0 & 2 \\
Biology/Life Sciences & 3 & 0 & 0 & 3 \\
Ag/Bus\&Ag/Forestry\&Ag/Ag\&Vet Med/ & & & & 5 \\
$\quad$ Ag\&Economics & 1 & 1 & 3 & 5 \\
Physics/PhysicalScience/Phy\&Math/ & 3 & 2 & 0 & 4 \\
$\quad$ PhySci\&E/PhysOptAstr & 2 & 2 & 0 & \\
Science/Sci\&Eng. & 6 & 4 & 2 & 12 \\
Eng/E\&CS/Eng,Arch,\&City Plan/Eng, & 5 & 6 & 1 & 12 \\
$\quad$ Math,CS/Tech \& Aviation/Textiles & 27 & 18 & 6 & 51 \\
Music & & &
\end{tabular}

as being in the "Other" category, and these were from four "Branch" categories: agriculture, engineering, earth sciences, and music. In fact, agriculture had as many in "Other" as it had in the "Main" and "Branch" categories combined. From the comments and through examination of the two agriculture sites in the "Other" category for which the URL of the public computer home page screen site was given by

\section{It is clear that some librarians, although presenting the main library page as the default page for their patrons, would prefer to present their own branch page.}

the respondent, it was determined that the content of these sites emphasizes the databases, CD-ROMs, and electronic journals available to library patrons. One of these agriculture libraries has a separate computer for accessing the online catalog. One of the three "Other" respondents commented that the "public" branch library page answers questions about location, hours, policies, and so on and that there are links both ways for the two sites. These comments provide insight into the rationale for the use of a public computer home page screen that is different from the branch library's home page.
Responses from the music librarians gave that subject area the greatest total number of responses by subject- - twentyfive $(31 \%)$ of the eighty responses in the three categories. Fifteen of these responses for the music branches were in the "Branch" category and represent 45 percent of the total responses in that category. The total for all branches except music is also given in table 3 . The remaining branches, now all in the science, engineering, math, agriculture, and architecture areas, somewhat favor the choice of "Main" (56\% of the total).

Table 4 gives the results calculated only for ARL libraries. For the ARL libraries, the music results were not as dominant. Again, the "Main" category was slightly more favored with 53 percent of the total.

The results of table 3 are represented in chart form in figure 1. Figure 2 shows the results for all respondents with the branch types grouped into five subject categories. With similar subject areas combined, it is more visually apparent that the science areas favor using the main page whereas music favors using the branch page.

Figures 3 and 4 repeat the type of information in figures 1 and 2 compiled only for ARL libraries. These figures show the same tendency in the ARL libraries. Interestingly, architecture results are more 


\section{FIGURE 1}

Types of Home Page Used by Branch Libraries by Subject Area, All Respondents

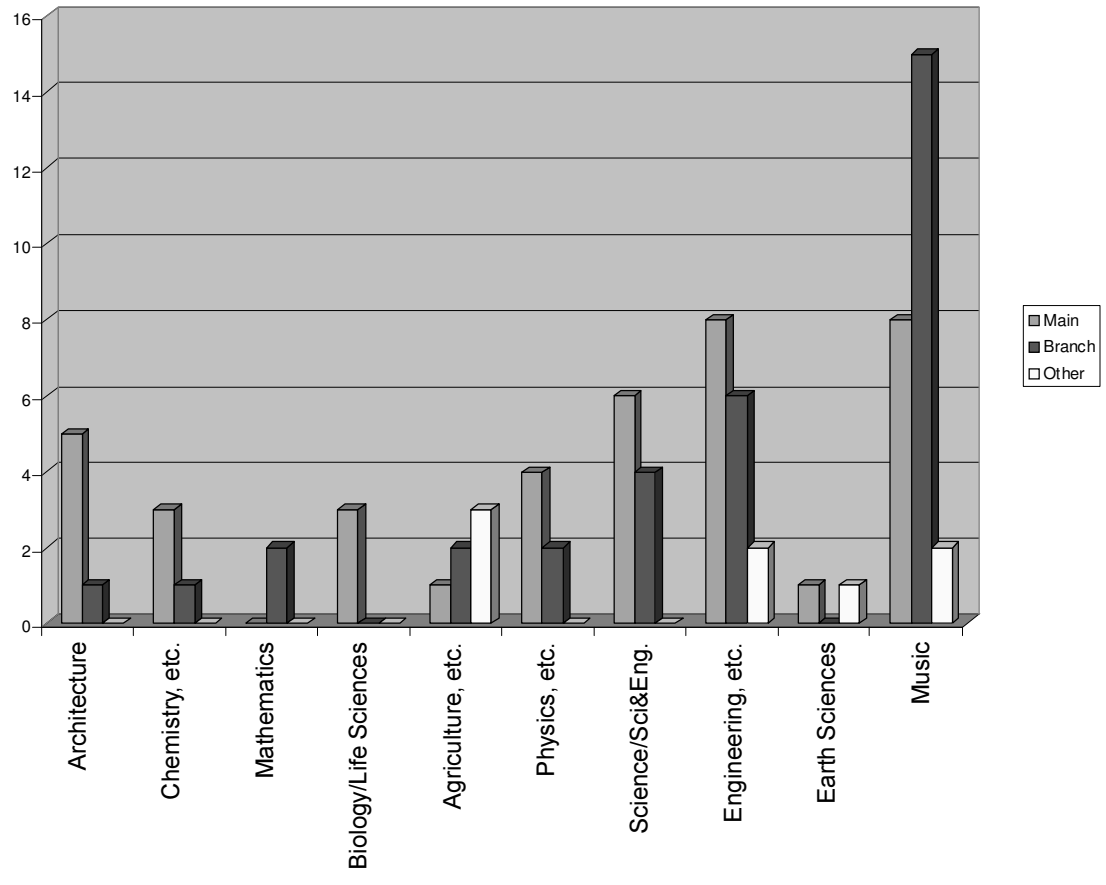

FIGURE 2

Type of Home Page Used by Branch Libraries by Subject Area, Branches Combined

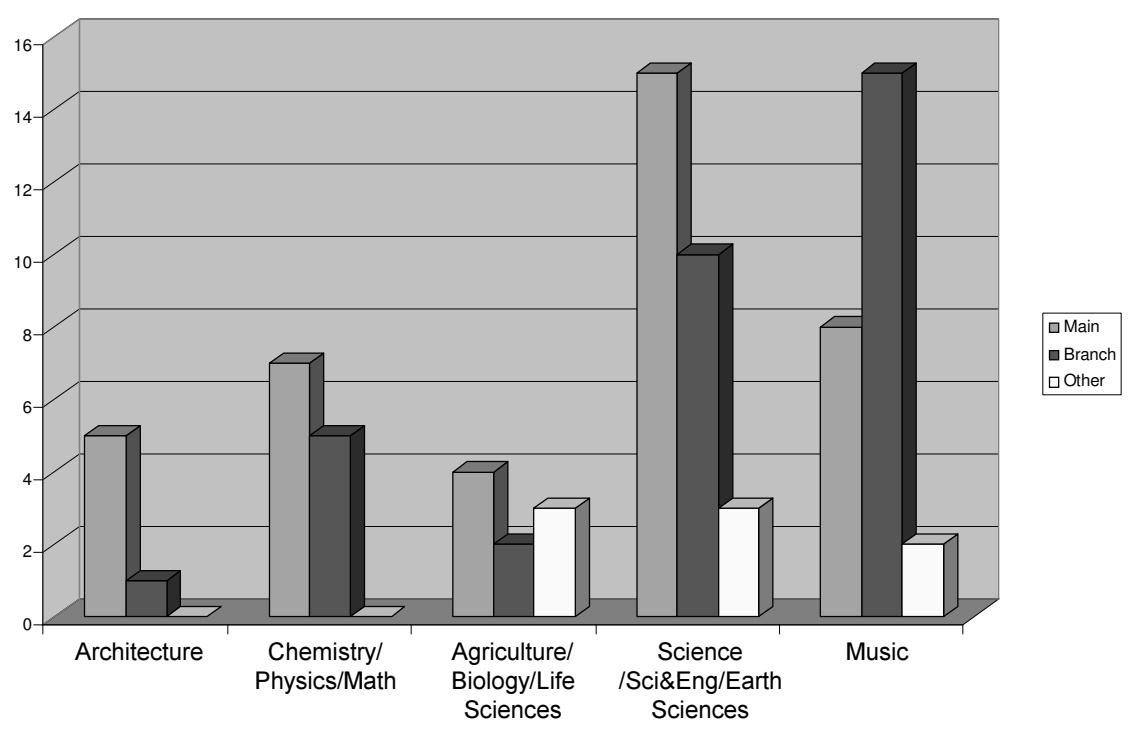


FIGURE 3

Type of Home Page Used by Branch Libraries by Subject Area, ARL Only

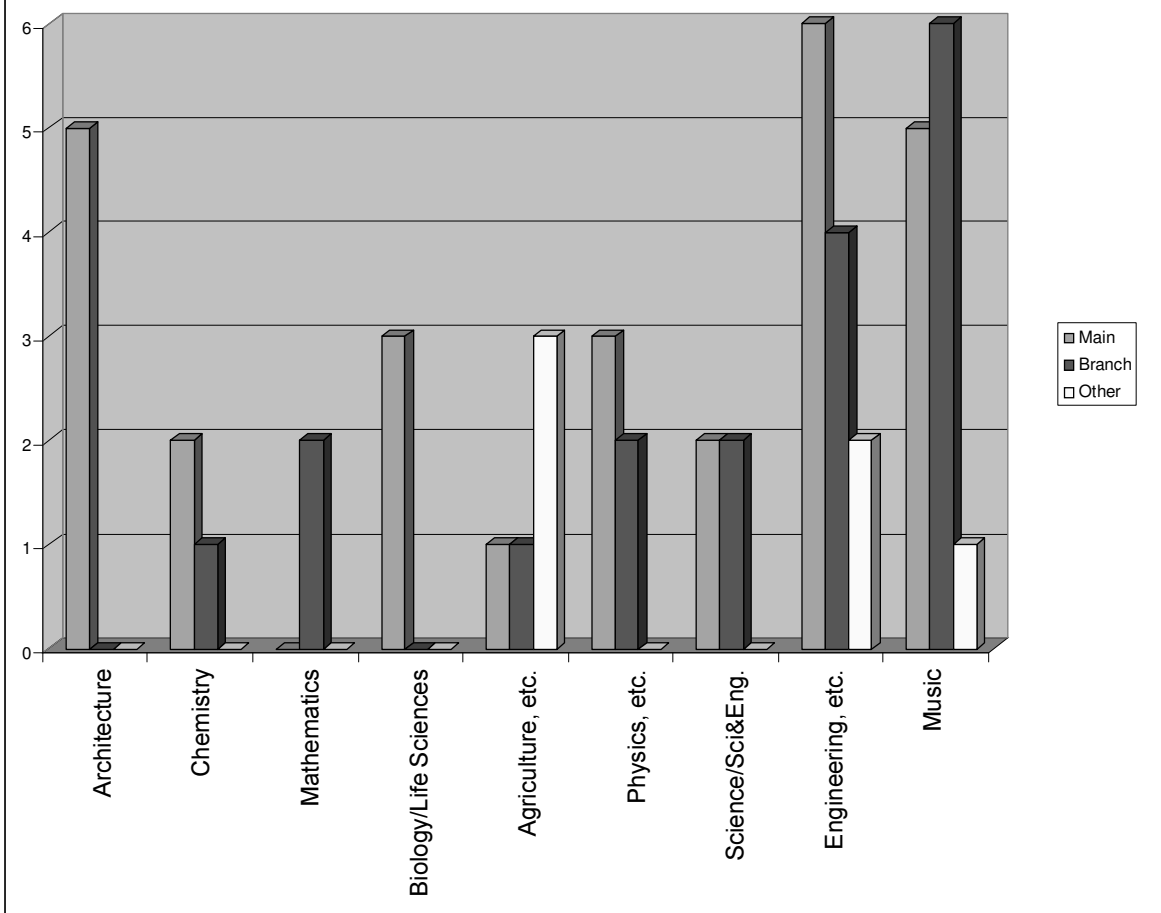

FIGURE 4

Type of Home Page Used by Branch Libraries by Subject Area, ARL Only, Branches Combined

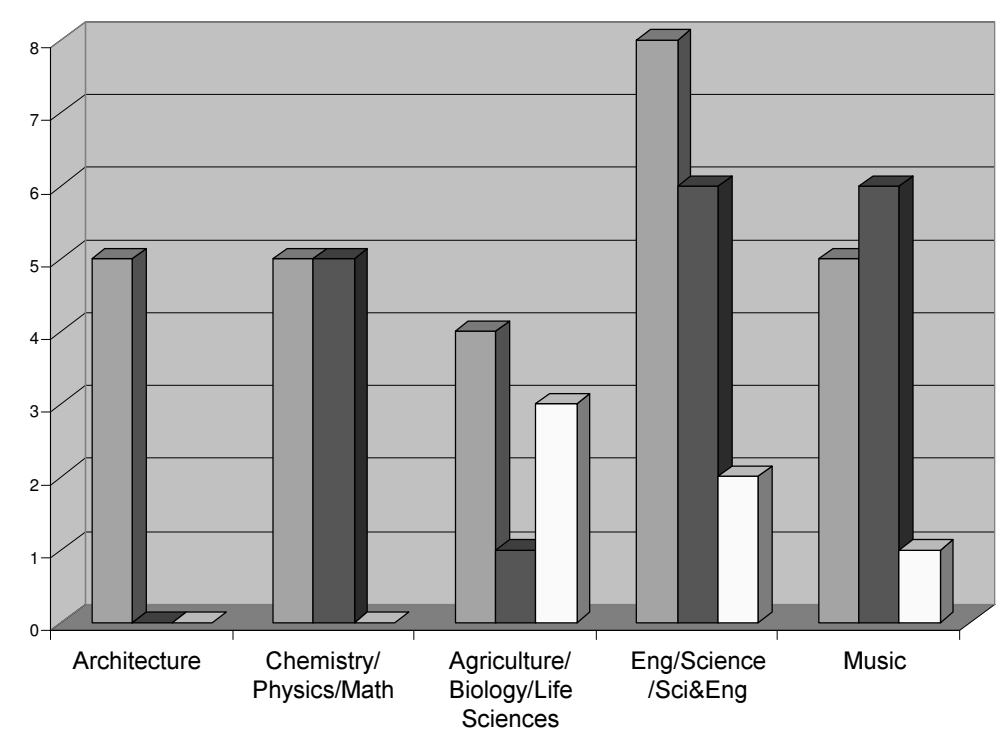


aligned with the science results than with the humanities (music) results.

In the questionnaire, librarians were invited to relate any experience they had regarding the issue of default Web pages. Although the results show that more branch libraries use the main Web site as their default screen, the comments received tended to favor the use of the branch site as the default screen. The comments also give a different view into the decision-making process in libraries than the results do. ${ }^{19}$

Some comments tended to favor using the main library Web page as the default. "I (and my colleagues) feel that it is important for the music majors to see everything available to them," said one librarian. ${ }^{20}$ Another librarian said, "Uniformity across campus is important. Admin[istration] wants patrons to see the same thing regardless of where on campus they happen to be. Less confusing that way." A similar voice said, "The feeling was that people should be able to walk into any library branch and be able to see the same starting point. They don't have to figure out how to get to the same resources in different ways depending on which physical location they are in." Still another commented that using the main page "allows easy enough access to most of our resources without having to duplicate efforts." Listserv comments indicated that the primary reasons for using the main library Web page as the default page were (1) interest in uniformity across campus, (2) depth of resources shown to the patron, and (3) nonduplication of effort.

There were a few unhappy voices in the main library mix. "Our central library administration refuses to budge on allowing the departmental libraries to use their own Web pages as the default in the public computers in the departmental libraries," said one librarian. Another commented, "I'm not thrilled with [our] arrangement. There's too much interest in uniformity." It is clear that some librarians, although presenting the main library page as the default page for their patrons, would prefer to present their own branch page.

Of the librarians who reported using a branch Web page as the default page, there were some optimistic statements. One librarian happily reported, "We have our own home page to which our OPACs default. No problems! Some compliments, in fact-from the few who notice! - as we can tailor everything to the needs of [our] patrons." Another asked: "Why should the subject specialists who know best what their patrons need, devote significant time to crafting ever more useful navigational tools to our resources, and then make them so difficult for patrons to get to?"

\section{Dissension aside, there is something to be said for the library system that has made the conscious decision toward consistency in all libraries.}

Other comments questioned the relationship between branch librarians and other library offices. Several mentioned that they would prefer using their own branch home page, but their systems office vetoed the idea. One librarian confessed, "Our Web page is woefully out of date, but once it is updated I might push to have our page the default in our library.... I suspect there will be resistance."21 Another said, "The issue of branch library home pages is a sticky one here, too. The main library would like our pages to look just like theirs whereas we have always had something a bit more distinctive and geared to [our] students and programs." The primary reason mentioned for using the branch Web page as the default page was that a librarian knows his or her patrons and can tailor a page to their specific needs.

Other issues that librarians deemed worthy of comment included autonomy, the appearance of the page, and the number of clicks it takes to get to important resources. Regarding autonomy, one librarian complained that "The main library's Webmasters have control over the files and, therefore, [the] content of the page. The Internet resources and database connections were zapped without notice from the [branch] library page." Regarding the page's appearance, a librarian stated, "Turf wars are possible over how similar or dissimilar the branch library's 
Web page looks compared with the main library's page." One librarian talked about mouse usage: "The students and faculty want to go where the goodies are with as few 'clicks' as possible." Another comment reflected a general hopelessness about any decisions we make about default screens: "I don't think it matters what we have on the screen. Our patrons will ignore it and type in the URL of whatever they're going to. I've watched several students type in the university's main page, then select "Libraries" from that and THEN go to the catalog, going back through the page they started at." Clearly, many issues involving, among other things, internal library politics and actual usage come into play.

The comments gathered in the survey show the variety of concerns that dedicated librarians consider when deciding what interface to present to their patrons. In those libraries where the main Web site is used as the default screen, some librarians support the choice. For other libraries, choice of the main Web site is determined at a higher level of administration and the librarians wish it could be otherwise. The comments reflect these desires.

\section{Conclusions}

The results of the questionnaire show that slightly more branch libraries use a main library Web site instead of a branch library Web site as the default Web site on public access computers in their libraries. However, a slight preference for using a personalized branch site is reflected in the comments of branch librarians on their desires for their Web sites. Nobody using a branch page wished he or she had a main page to use instead.

There are solid reasons to make either choice. The benefits of using a branch page as the default page include:

- A page can be tailored to the needs of a specific group of library users.

- The needed resources for a specific library type can be accessed directly from the top page.

- The branch library has greater autonomy to make decisions about what is most important for its patrons.
The benefits of using a main library Web site as the default page include:

- The presentation of the library system by its Web site is consistent across campus.

- Agreater variety and greater depth of resources are shown to the patron.

- The effort of creating a usable Web page is centralized in the library system and not duplicated.

A librarian can responsibly defend either choice.

Other factors that may be variable on different campuses are:

- the proximity of the branch to the main part of the campus;

- the frequency of use by students not majoring in the subject area of the branch;

- the extent and importance of interdisciplinary research on the campus;

- the importance of ready access to information sources from a variety of fields at the branch.

Perhaps the most important factor is the actual consideration of these issues by personnel in the library system. Dissension aside, there is something to be said for the library system that has made the conscious decision toward consistency in all libraries, whether the decision results in use of the main library Web page at all branches, a separate and distinct research gateway at all public access computers, (or some subset of them), or allowing each branch to develop its own site, perhaps with some standard requirements.

The research gateway sites and many of the branch library Web sites that fall into the "Other" category may represent the most valuable consideration of all. For the most part, these are the sites that have specifically tailored their default screens on their public access computers to meet the needs of the library patron who comes into the library to do research.

There are issues pertinent to a library's choice that could benefit from further research. For instance, how easy is it to find the branch Web page from the main Web page, and vice versa? With the use of either default screen, having the other Web site easily available to a patron would be 
valuable. Another vital issue is the look of the page. Are the main library Web site and the branch library Web site similar in appearance? Do they use the same logo or branding? Are the navigation choices similar? Yet a third issue is the number of clicks it takes to get to a desired database. If an architecture student wishes to search the Avery Index to Architecture Periodicals, how many clicks does it take to access the database from the main Web site? Is the database closer to the top screen on the architecture library Web site? Is there an annoyance factor for the patron that can be lessened by presenting the Avery Index on the top page of the architecture library's
Web site? Further research on these factors may help clarify the issues of default home page choice, design, and content.

\section{Epilogue}

Since the writers did this study, and partially because of it, their library system devised a compromise. The OPACs at each library on campus are set up with a desktop in two parts. The top part is standard; the bottom part can be filled with icons to provide access to important resources for the branch: databases, research guides, or the branch library's home page. It is too early to tell how well this compromise is working.

\section{Notes}

1. Nestor L. Osorio, "Web Sites of Science-Engineering Libraries: An Analysis of Content and Design," Issues in Science and Technology Librarianship 29 (winter 2001). Available online from http:/ / www.library.ucsb.edu/istl/01-winter/refereed.html.

2. By "main library Web site," the authors are referring to an overall library Web site, not just the site for the main library. This would be the site that appears when a patron clicks on "Libraries" on the institution's Web site.

3. Eelko K. R. E. Huizingh, "The Content and Design of Web Sites: An Empirical Study," Information $\mathcal{E}$ Management 37 (Apr. 2000): 133.

4. "ACRL Guidelines for Branch Libraries in Colleges and Universities," College E Research Libraries News 3 (Mar. 1991): 171.

5. Ibid., 172.

6. Olivia M. A. Madison, Sally A. Fry, and David James Gregory, “A Model for Reviewing Academic Branch Libraries Based on ACRL Guidelines and Standards," College E Research Libraries 55 (July 1994): 350.

7. Ibid., 343.

8. Leon Shkolnik, "The Continuing Debate over Academic Branch Libraries," College E Research Libraries 52 (July 1991): 348.

9. Odin Jurkowski, “The Evolution of Academic Branch Libraries," Illinois Libraries 80, no. 1 (winter 1998): 27.

10. Ibid., 28.

11. Madison, Fry, and Gregory, "A Model for Reviewing Academic Branch Libraries," 345-46.

12. Laura B. Cohen and Julie M. Still, "A Comparison of Research University and Two-year College Library Web Sites: Content, Functionality, and Form," College E Research Libraries 60 (May 1999): 275-89.

13. David L. King, "Library Home Page Design: A Comparison of Page Layout for Front-Ends to ARL Library Web Sites," College E Research Libraries 59 (Sept. 1998): 458-65.

14. Barbara I. Dewey, "In Search of Services: Analyzing the Findability of Links on CIC University Libraries' Web Pages," Information Technology and Libraries 18, no. 4 (Dec. 1999): 212.

15. Karen Diaz, "The Role of the Library Web Site: A Step beyond Deli Sandwiches," Reference $\mathcal{E}$ User Services Quarterly 38, no. 1 (1998): 43.

16. Ibid., 43.

17. Steven Sowards, "A Typology for Ready Reference Web Sites in Libraries," First Monday 3, no. 5 (1998):5. (http:/ / www.firstmonday.dk/issues/issue3_5/sowards/index.html):

18. Association of Research Libraries, "ARL Member Libraries' Information Servers." Available online from http:/ / www.arl.org/members.html.

19. The comments in the next five paragraphs were taken from e-mails received in the fall of 2000 and winter of 2001. Most are presented anonymously following the wishes of the respondents.

20. Suzanne Gertig-Moulton, e-mail communication, Feb. 12, 2001.

21. Sarah Dorsey, e-mail communication, Feb. 12, 2001. 